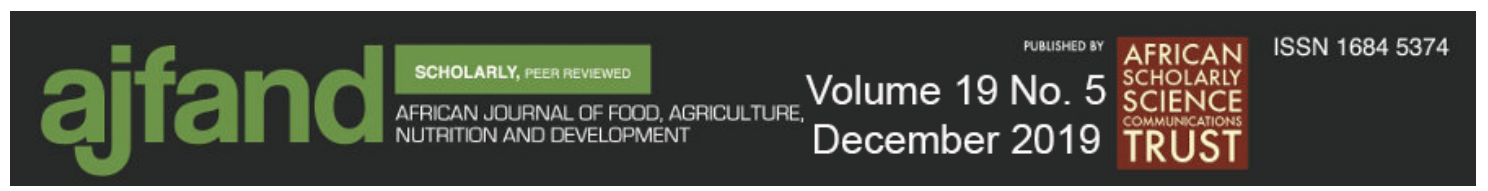

University of Illinois - SIL Farm.Doc Series

Afr. J. Food Agric. Nutr. Dev. 2019; 19(5): 15151-15154 DOI: 10.18697/ajfand.88.SILFarmDoc09

\title{
SOYBEAN PESTS
}

H. M. Murithi ${ }^{1}$, E. N. Wosula ${ }^{2}$, D. M. Lagos-Kutz ${ }^{3}$ and G. L. Hartman ${ }^{4}$

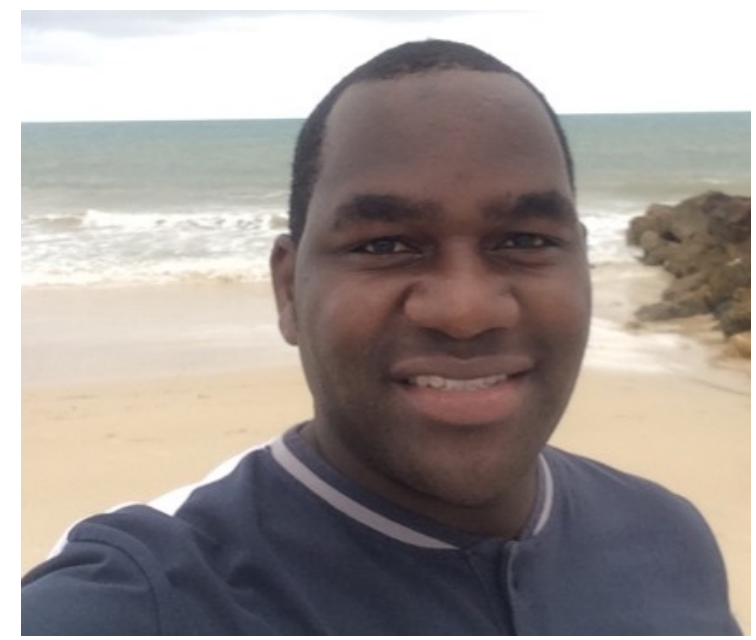

Harun Muthiri

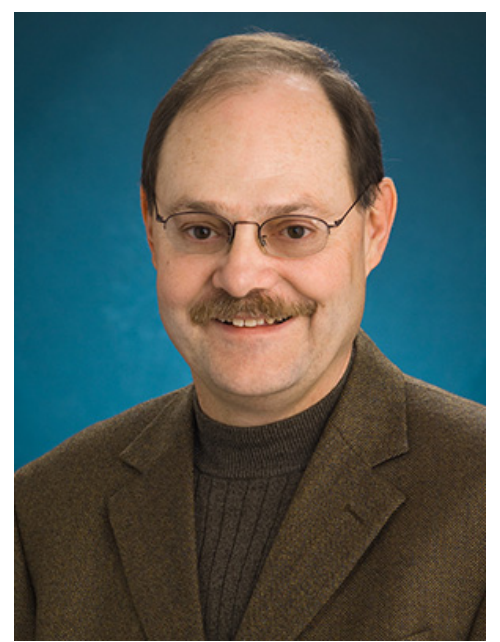

Glen Hartman

About the Authors

${ }^{1}$ Dr. H. M. Murithi, is a plant pathologist with USDA, Agricultural Research Service

Email:hmurithi@gmail.com

${ }^{2}$ Dr. E. N. Wosula is a vector entomologist with the International Institute of Tropical Agriculture (IITA), Dar Es Salaam, Tanzania

${ }^{3}$ Dr. D. M. Lagos-Kutz is with USDA, Agricultural Research Service

${ }^{4}$ Dr. G. L. Hartman is with USDA, Agricultural Research Service and Department of Crop Sciences, University of Illinois at Urbana-Champaign

Email: ghartman@,illinois.edu 
Soybean pests attack at any growth stage from the seedling through to harvest and can be especially severe from flowering to plant maturity. The pests reduce quality and yields of soybean. Soybean pests cause damage through direct feeding thereby exposing plants to attack by other pathogens and indirectly by transmission of viruses and other pathogens (Heinrichs and Muniappan, 2018).

The expected increase in soybean production in Africa will likely lead to increase in occurrence of soybean pests. Soybean pests are likely to be introduced through trade of grain, exchange of breeding materials across the globe, and by natural means like water and wind. Although soybean pests have not been sufficiently investigated in Africa, a few common pests have been identified. Of the soybean pests occurring in Africa, pod borers are among the major pests due to their wide host range. For instance, in cowpea the lima bean pod borer (Maruca vitrata) and the pod borer (Helicoverpa armigera) feed on the flower buds, flowers and pods resulting to yield losses of between 20 and $80 \%$ (Sharma, 1998). Biological control of Maruca vitrata has been successful in controlling the damage it causes on cowpea (Tamo et al., 1997).

Soybean stem flies also known as soybean stem miner (Melanagromyza sojae) is a common pest in Africa especially in Egypt (Arnemann et al., 2016, Abdallah et al., 2014). Ovipositioning occurs on the undersides of leaves after which yellow maggots emerge and mine through the leaf extending towards the leaf petiole into the stem. This damages the vascular tissues leading to plant wilting and reduced soybean yield (Heinrichs and Muniappan, 2018).

Stink bugs feed on pods and seeds affecting seed germination, quality and may lead to pod distortion. The pods eventually detach from the plant. The southern green stinkbug (Nezara viridula) is native to Ethiopia and apart from soybean, the pest is known to cause damage to more than 50 host plants (Heinrichs and Muniappan, 2018). Yield losses ranging from $25 \%$ to $60 \%$ have been recorded in Nigeria (Jacaki et al., 1988). The bugs inject toxins into pods and seeds leading to necrosis. The affected pods are shriveled and the seeds are discolored.

Damage by this pest can cause low seed oil content (Heinrichs and Muniappan, 2018).

Green semilooper (Thysanoplusia orichalcea) larvae that has a distinct looping pattern, feeds on the underside of the leaves causing widow like feeding patterns. The larvae prefer feeding on the lower canopy. Severe infestation causes defoliation of the whole plant (Gau and Mogalapu, 2018).

The groundnut leaf miner (Aproaerema modicella) is a fairly new important pest of soybeans in Uganda. The pest, also known as webworm was first observed on soybean in Uganda in 2011 (Namara et al., 2019). The pest was earlier observed on soybean in South Africa in 2001 (du Plessis, 2002). The larvae mine the leaf midrib (Fig. 1), the leaves become brown, roll down (Fig. 1) and eventually drop off. Losses of more than $50 \%$ have been reported on groundnut (Cugala et al., 2010). Yield losses on soybean 
range from 37 to $65 \%$ in Uganda (Namara et al., 2019). Moderately resistant exotic varieties and two commercial lines have been identified among the 160 genotypes that were tested in Uganda (Namara, 2015).

Bruchid beetles (Callosobruchus spp.) are the most common storage pests of legumes. The pest lays eggs on pods before harvest and carry over into storage. The larva feeds within a single seed excavating chambers as it grows. The damage affects seed quality and germination. Damage on soybean seeds by adzuki bean weevil (Callosobruchus chinensis) has been reported in Uganda (Msiska et al., 2018).

Plant parasitic nematodes have been identified as important pests of soybean in Africa (Fourie et al., 2015). More than 48 nematode species comprising about 18 genera have been associated with soybeans in South Africa. The root-knot nematodes on soybean cause the most damage resulting to yield losses ranging from 25-70\% (Fourie et al., 2015). Nematodes produce numerous galls on soybean roots due to feeding and laying of eggs. The infected plants become stunted, yellowish and wilt (Lima et al., 2017). More studies are required to investigate the effect of the nematodes on the other soybean growing areas in Africa.

\section{References}

Abdallah, F. E., Boraei, A. H., \& Mohamed, H. M. (2014). Susceptibility of some soybean varieties and effect of planting dates on infestation with soybean stem fly, Melanagromyza sojae (Zehnt.) at Kafr El-Sheikh region.

Journal of Agricultural Research Kafr El-Sheikh University, 40, 390-400.

Arnemann, J. A., Tay, W. T., Walsh, T. K., Brier, H., Gordon, K., Hickmann, F., Ugalde, G. and Guedes, J.V.C. (2016). Soybean Stem Fly, Melanagromyza sojae (Diptera: Agromyzidae), in the New World: detection of high genetic diversity from soybean fields in Brazil. Genet Moleculat Research, 15(1), 1-13.

Cugala, D., Santos, L., Botao, M., Solomone, A., \& Sidumo, A. (2010). Assessment of groundnut yield loss due to the groundnut leaf miner, Aproaerema modicella infestation in Mozambique. In Second RUFORUM Biennial Meeting, Entebbe, Uganda.

Du Plessis, H. (2003). First report of groundnut leafminer, Aproaerema modicella (Deventer)(Lepidoptera: Gelechiidae) on groundnut, soybean and lucerne in South Africa. South African Journal of Plant and Soil, 20, 48- 48.

Fourie, H., De Waele, D., Mc Donald, A. H., Mienie, C., Marais, M., \& De Beer, A. (2015). Nematode pests threatening soybean production in South Africa, with reference to Meloidogyne. South African Journal of Science, 111, 01-09. 


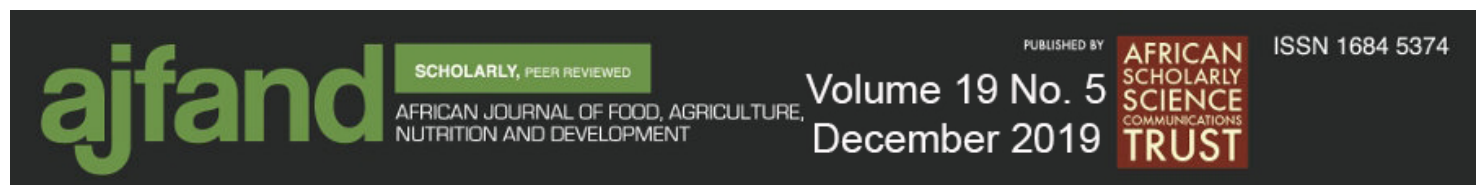

University of Illinois - SIL Farm.Doc Series

Gaur, N., \& Mogalapu, S. (2018). Pests of Soybean. In Pests and Their Management (pp. 137-162). Springer, Singapore.

Heinrichs, E. A., \& Muniappan, R. (2018). Integrated pest management for tropical crops: soyabeans. CAB Reviews, 13(055), 1-44.

Jackai, L. E. N., Dashiell, K. E., \& Bello, L. L. (1988). Evaluation of soybean genotypes for field resistance to stink bugs in Nigeria. Crop protection, 7, 48-54.

Lima, F. S., Correa, V. R., Nogueira, S. R., \& Santos, P. R. (2017). Nematodes affecting soybean and sustainable practices for their management. Soybean-the basis of yield, biomass and productivity. IntechOpen, 95-110.

Msiska, U. M., Odong, T. L., Hailay, M., Miesho, B., Kyamanywa, S., Rubaihayo, P. R., \& Tukamuhabwa, P. (2018). Resistance of Uganda soybean germplasm to Adzuki bean bruchid. African Crop Science Journal, 26, 399-415.

Namara, M., Tukamuhabwa, P., \& Karungi, J. (2015). Resistance of soybean germplasm to the groundnut leaf miner (Aproaerema modicella) in Uganda. RUFORUM.

Namara, M. (2015). Resistance of soybean germplasm to the groundnut leaf miner (Aproaerema modicella) In Uganda (MSc dissertation, Makerere University).

Sharma, H. C. (1998). Bionomics, host plant resistance, and management of the legume pod borer, Maruca vitrata - a review. Crop protection, 17, 373-386.

Tamò, M., Bottenberg, H., Arodokoun, D., \& Adeoti, R. (1997). The feasibility of classical biological control of two major cowpea insect pests. Advances in cowpea research, 259-270.

Venette, R. C. and Ragsdale D. W. (2004). Assessing the Invasion by Soybean Aphid (Homoptera: Aphididae): Where Will It End? Annals of the Entomological Society of America, 97(2), 219-226. 